\title{
Celebration of Violence in N. F. Simpson's One Way Pendulum and the Form
}

\author{
${ }^{1}$ Anindita Das, ${ }^{2}$ Dr. Dipendu Das, \\ ${ }^{1}$ (Assistant Professor, Department of English, N. N. Saikia College, Titabar, India), \\ ${ }^{2}$ (Associate Professor, Department of English, Assam University, Silchar, India)
}

\begin{abstract}
Violence may be defined as the deliberate use of power or physical force against oneself or some other entity. It involves a power relationship between the tormentor and the victim. And so, threats and intimidation may also be considered acts of violence. The use of violence or force in every sphere of human life has become a common feature of the world after the World War II. The dramatists of the theatre of the absurd have highlighted it not only in the themes of their plays but also in their language. N. F. Simpson's plays One Way Pendulum (1959) and The Form (1961) deal with the theme of violence, which is both physical and verbal. Taking recourse to violence is a means of escape for the individual both from his own self and the world outside. The play is about Kirby's inhuman obsession with violence. He is merely engrossed in the celebration of mindless violence. In Simpson's The Form, we find how the unemployed Whinby usurps the authoritative position of his employer Mr. Chacterson by mastering the act of verbal violence, The intruder celebrates such violence and the victim willingly surrenders himself to the same. This paper is an attempt to study the strange manifestations of violence in postwar world as depicted in both the plays by Simpson.
\end{abstract}

Keywords - Violence, power, absurd, escape, celebration

\section{Introduction}

Violence is the intentional use of power against a person, community or some other entity. It may be actual or threatened. Violent acts generally spring from a power relationship. All kinds of physical, psychological and sexual abuse done to others or oneself fall within the purview of violence. Threats and intimidation are also regarded as acts of violence. Violence is one of the dominant themes of the theatre of the absurd. N. F. Simpson deals with the theme of violence in his plays in a way that seems to be characteristically his own. This paper is an attempt to study the various manifestations of violence-thematic, verbal and spatial - by Simpson in his plays One Way Pendulum (1959) and The Form (1961). An intentional act of violence meant to cause harm to others or oneself is a crime. Humans down the ages have always had an irresistible fascination with crime and violence. People, in general, always tend to get fascinated about the dark, ugly, mysterious part of other people's lives. The treatment of crime and violence is a subject that has eternally been chose by dramatists and writers all over the globe. Our culture's drama is primarily provided by the enigmatic consequences and trials of various crimes or acts of violence. Theatre deals with theme of crime and violence, and so it always unmistakably engages the public's attention. The European absurd dramatists of the twentieth century have also dealt with the concept of violence and have manifested violence in their plays in multiple ways. We find such manifestation of violence in not only the themes of their plays but also in the language and the spectacle.

\section{One Way Pendulum-the Play}

One Way Pendulum is about a seemingly steady and quiet family, the Groomkirbys. When the play opens it seems to be a normal household. However, such a consideration is gradually questioned and shattered as the play develops. All the various prosaic preoccupations, which constitute the monotonous everyday life of the Groomkirbys, prove quite mad and eccentric. The father, Arthur Groomkirby is obsessed with reconstructing a replica of Old Bailey court in his living room; his son Kirby is crazily engaged in training five hundred Speakyour-weight machines to sing a holy Chorus; while the mother, Mabel Groomkirby is restlessly absorbed in cleaning the household by working hard all day and also by employing a woman not to help with the cleaning but merely to eat up the leftovers after every meal; and Aunt Mildred, in her wheel chair, is endlessly engrossed in planning her exotic trip to the Outer Hebrides. The theme of violence in the play is most intimately linked to the character called Kirby Groomkirby. Kirby has a diehard desire to wear black all the time throughout his life.

And he wants to provide himself with a logical pretext in order to do so. Therefore, he takes up the task of killing people on a regular basis so as to mourn over their deaths by wearing black as a sign of mourning. He is almost incessantly engaged in training five hundred Speak-your-weight machines to sing the Hallelujah Chorus. Kirby behaves like an automaton, and ironically enough, is engaged in the absurd task of humanizing 
machines so as to entrap humans and kill them. The plan is to make them sing the chorus at the North Pole so as to attract people to the spot wherefrom Kirby can push them into the valley of death, that is, the Arctic Ocean, after each one of them a joke and striking each with an iron bar. He, in fact, celebrates such violence by wearing black with a sense of pride; he celebrates the accomplishment of this bestial task that enables him to fulfil the one and only purpose of his life - to wear black permanently. Martin Esslin aptly comments on the depiction of English suburban life in the play: "One Way Pendulum portrays a society that has become absurd because routine and tradition have turned human beings into Pavlovian automata" [1].

\section{Celebration of Violence}

What is striking about the play is that Kirby is almost speechless throughout the text. His acts of violence are only reported on the stage by other characters. He may be called a character without a voice. He only appears on the stage on two occasions - just before the end of each of the two acts of the play. His father wants him to be tried for his crime in a court of law, and so the former converts the living room of his house into a replica of the Old Bailey court wherein a trial of Kirby's crime is conducted by a Judge who is assisted by a Prosecuting Counsel and a Defence Counsel. Robert Barnes, the police sergeant who arrested Kirby, tells the judge:

"For the last year or two he's been studying what he calls logical analysis, and this has gradually taken the form of looking for a logical pretext for wearing his black clothes" [Pendulum, Act Two, 81] [2].

And, the Prosecuting Counsel remarks:

"He seems to have been using the same technique fairly consistently, m'lord. He tells his victim a joke, waits for him to laugh, and then strikes him with an iron bar" [Pendulum, Act Two, 79].

The Prosecuting Counsel also reports that the accused has already killed forty-three people and that he has been arrested before he could commit the forty-fourth offence. Kirby seems to be insanely infatuated with violence. However, he is not the only one who indulges in the celebration of such mindless violence. The court itself celebrates such violence and brutality by dealing with the serious criminal case in an absurdly comic manner. Kirby's heinous crime is looked upon by the Judge as a simple forgettable joke. The Judge opines that a criminal can be sentenced to death for one particular crime and that he cannot be sentenced for more than one criminal offence. He uses his twisted logic to drive home his point:

"...in sentencing a man for one crime, we may be putting him beyond the reach of the law in respect of those other crimes of which he might otherwise have become guilty. The law, however, is not to be cheated in this way. I shall therefore discharge you" [Pendulum, Act Two, 92].

Such a celebration of violence and injustice is no longer funny. It is a shame to the court of law; it is shame to the judicial system; a shame, indeed to humanity as well. The play, therefore, implicitly comments on the social reality of celebration of violence and inhumanity by the contemporary judicial system. Criminals who deserve severe punishment most often remain beyond the reach of the law because there is always some twisted, anarchic, absurd logic at play within the court-room. There are also instances of verbal violence in One Way Pendulum. That is to say, violence has also been manifested in the use of language. The greatest irony in the play is that while the accused is set free without any sort of physical or mental harassment, his father is cruelly subjected to verbal violence in the court-room. The father, Mr. Arthur Groomkirby was called to the witnessbox by the Judge himself. Mr. Groomkirby's sense of self-respect and self-confidence is almost shattered by the Judge and the Prosecuting Counsel who tend to humiliate and belittle him by all means. The hypnotic language used in the court-room carries with itself the prospect of inevitable violence. The Prosecuting Counsel asks Mr. Groomkirby:

"...I want to cast your mind back a little way to the summer of last year. To the twenty-third of August. Do you happen to remember where you were, or what you were doing, on that day?" [Pendulum, Act Two, 62] Further, he asks Mr. Groomkirby:

"You must have spent a good many hours in sleep since last August?" [Pendulum, Act Two, 66]

Mr. Groomkirby replies in the affirmative, and then the Prosecuting Counsel finds out that the witness has also taken a number of meals since last August. This absurd interrogation makes him throw yet another question:

“...the normal processes of what is known sometimes as metabolism, whereby body tissue is constantly

being

built up or broken down, have been going on unceasingly since the twenty-third of August last year?" [Pendulum, 67]

Then, the Prosecuting Counsel applies his absurd logic to arrive at an authoritative conclusion:

"....in view of these changes the man you say was in Chester-le-Street last year is not the man who is standing in the witness box at this moment" [Pendulum, Act Two, 67].

The Judge, too, attacks Mr. Groomkirby with his cruel and sarcastic words:

"Cold, blind, deaf - and now dumb! For God's sake, Mr. Groomkirby! Put your earplugs back in!" [Pendulum, Act Two, 75] 
The Judge, strangely enough, hesitates to let the witness Mr. Groomkirby be set free even after subjecting him to threats and intimidation that have damaged his sense of his own identity. The Judge threatens the latter with the intention of taking some legal action against him:

"The law would be moribund if it were unable to deal with a case such as this, and I should be failing in my duty if I were to allow a man of the kind you have shown yourself to be to go at large" [Pendulum, Act Two, 70].

\section{Spatial Manifestation of Violence}

Violence seems to manifest itself spatially in the play in terms of the spectacle. The living room of the Groomkirby household is found to have been transformed into the court-room from the very opening of Act Two. The furniture of the living room has been crowded to one side in order to use the space as the court-room. This dramatic spatial transformation within the household has been brought about by Mr. Groomkirby. He has converted his living room into a replica of the Old Bailey court. His wife Mrs. Groomkirby, naturally, finds it difficult to move about within the living room. She has always been gripped by the fear of having to face such unpleasant circumstances: One, 39].

"What I'm dreading is the day he brings the Old Bailey home for us all to fall over" [Pendulum, Act

Her strong desire to clean up the household and to keep things in order is violently shattered by her husband's forcible intrusion into her exclusive domain in the domestic sphere. She cannot do anything to prevent such violent intervention, and so she endures and almost celebrates the violent change within the household. This spatial manifestation of violence, perhaps, springs from a psychological conflict in Mr.

Groomkirby. This inner conflict arises from his awareness of his son's crime, from his anxiety about the latter's arrest, from his inability as a father to reform his own son who has turned a criminal and his desire to help his son by making the latter face the trial in his court-room that has been constructed by him for the purpose. Whether it is a real court-room or merely a figment of his imagination is a matter of debate. However, what is significant is that it is the manifestation of a potentially violent inner conflict in Mr. Groomkirby.

\section{The Form-the Play}

Simpson's play The Form is also characterized by the celebration of violence that has been manifested both at the verbal and thematic levels. The play reveals how a job-seeker steps into an office to face an interview, how he eventually succeeds in compelling the officer to lose all his self-confidence, how he usurps the position of the officer and turns the latter out of his own office! The play is about a young man Whinby who arrives at Mr. Chacterson's office in search of employment. Whinby waits for quite some time in order to face his interview to be conducted by Mr. Chacterson. During the interview the employer Chacterson subjects Whinby to a sort of mental harassment by bothering him with too many questions and remarks. On being confronted with so dominating an interviewer Whinby suffers from a loss of self-confidence. He says to Chacterson:

"I don't seem to have the answers to the questions, somehow" [The Form, 13] [3]. And, Mr. Chacterson comments with an air of over-confidence:

"That's your trouble at the moment. You're paying too much attention to the questions. Looking for answers. Working them out as you go along. You've got to dominate the questions. If you don't dominate them, they'll dominate you" [The Form, 13].

The following remark by Chacterson is a telling instance of celebration of violence that finds expression in terms of Simpson's hypnotic language:

"It's the only thing. Kill the questions stone dead. Before they have a chance to get the upper hand. It's what they never realize, some of them" [The Form, 14].

It is Mr. Chacterson who dominates Whinby during their first interaction in The Form. Chacterson lectures authoritatively and Whinby listens helplessly for the latter is left with no other choice. Chacterson lectures on how to master the art of speaking effectively. Whinby internalizes the lesson Chacterson expects him to learn during the interview. Therefore, after the interview Whinby seems to be a changed man. He is no longer at the mercy of the employer Mr. Chacterson. Rather, absurdly enough, Whinby is found to occupy Chacterson's position in the office. He is the employer now and so he is addressed as Dr. Whinby by the receptionist Miss Haviour. He assumes absolute control over Chacterson's office and usurps the latter's position of power. Thus, Chacterson is rendered powerless, helpless and jobless after his second interaction with Whinby. It is now Whinby who interviews Chacterson. All on a sudden Mr. Chacterson finds himself on the other side of the table. 


\section{Verbal and Thematic Manifestations of Violence}

Whinby cleverly manages to manipulate things in his own favour by taking recourse to a sort of violence - verbal violence manifested in terms of threats and intimidation. The hypnotic dialogue bears within itself the prospect of impending danger and violence. Whinby violently victimizes Chacterson with his conclusive remarks and dictatorial ideologies leaving the latter in a state of enigma. He makes Chacterson lose his sense of his own identity and compels the latter to give up his original position of authority at the office. This is evident from Whinby's domineering manner of speaking to Chacterson:

"I attach a certain amount of importance to the spoken word ...but I attach if anything even more importance to the speaking voice. Which is ...the only vehicle ...for the spoken word. And the speaking voice is in my opinion something that far too few people ever really master. (He pauses) It's a question of pitch. Nothing more. Pitch and volume. If you can master the three basic things - pitch, volume, articulation bnyou can say with some degree of confidence that you've mastered the speaking voice" [The Form, 16, 17].

Chacterson is totally defenceless in the face of the changed circumstances. Whinby's sudden intrusion shocks Chacterson and removes him physically to the other side of the table. Employer turns job-seeker and is finally turned out of his own office! He realizes that there is no way in which he can regain his lost position of power, and so he willingly gives up. Instead of being angry with Whinby, he treats him with great respect. In the end of the play Chacterson thanks Whinby for sparing his time and for giving valuable advice. Chacterson walks out of the office that actually belonged to him a little while ago until he met the stranger Whinby! When there is no escape from the absurdity of life, one might even end up celebrating such absurdity and illogicality! The play, thematically, is about the celebration of the kind of verbal violence to which the manipulator Whinby subjects the victim Chacterson. What is striking is Kirby's inhuman obsession with violence. No pricks of conscience, no repentance at all. The play is all about the celebration of violence. He is not even aware of his alienation or estrangement from his own self as he no longer remains a human subject.

\section{Conclusion} one's life.

In Neema Parvini's opinion, "Simpson's plays demonstrate the absurdity of order as a ... means to live

His characters fail to connect with one another because of their subservience to ordered, inhuman modes of existence. If nothing else, the plays serve as a reminder that - even if there is no purpose to life, and although men and women are each free to make of themselves what they will - people all too easily get lost in their own machinations or those devised for them by society" [4]. It is also worth-noting that the primary characters in both the plays One Way Pendulum and The Form seek to establish their identity by taking recourse to some form of violence or the other. These plays by Simpson celebrate violence as the only means adopted by humans to manifest their sense of alienation from the world that seems to be indifferent and hostile to them.

\section{References}

[1] Martin Esslin, The Theatre of the Absurd (London: Methuen Drama, 2001)

[2] N. F. Simpson, One Way Pendulum (New York: Grove Press Inc., 1960).

[3] N. F. Simpson, The Form (London: Samuel French Ltd., 1961).

[4] Neema Parvini, N. F. Simpson and "The Theatre of the Absurd," Platform, 3 (1), 2009, 1-18. 